\title{
Empirical study of savings through life insurance in the Republic of Serbia
}

\section{Емпиријска студија штедње кроз животно осигурање у Републици Србији}

Marija Lukić

Faculty of Business Economics and Entrepreneurship, Belgrade, Republic of Serbia, Marija.lukic@vspep.edu.ra

Tatjana Piljan ${ }^{*}$

Faculty of Business Economics and Entrepreneurship, Belgrade, Republic of Serbia, tatjana.piljan@vspep.edu.ra Almir Muhović

Institute for Vegetable Crops, Smederevska Palanka, Republic of Serbia, amuhovic@institut-palanka.rs

Abstract: Life is a natural course, full of uncertainty and temptation of every human being. In order to make our lives more peaceful and have a more peaceful future, we are trying in various ways to secure ourselves and make our lives safer. Savings through insurance is a life-saving type of savings that involves the material protection of an individual against the risk of premature death and loss or loss of ability to earn money. In conditions where the solidarity-based pension system is unsustainable, it is necessary to develop voluntary pension insurance and savings through life insurance, as sources of long-term savings and additional sources of financing. The subject of this research is to answer the question of what people think about saving through life insurance. The main objective of this research is to evaluate the attitude of the residents of the Republic of Serbia towards saving through life insurance. The survey was conducted on the territory of the entire Republic of Serbia, on a suitable sample of 500 respondents. Through this paper, the citizens' attitude towards saving through life insurance in the Republic of Serbia is analyzed in one place. By analyzing the data from the survey, we can conclude that the general hypothesis is confirmed: Residents are not satisfied with the current state of savings through life insurance in the Republic of Serbia.

Keywords: life, savings through life insurance, material protection, long-term savings, additional source of financing.

JEL classification: G22, G23

Сажетак: Живот је природан ток, пун неизвесности и искушења сваког човека. Да бисмо свој живот учинили мирнијим и имали мирнију будућност, на разне начине покушавамо да се осигурамо и учинимо свој живот сигурнијим. Штедња путем осигурања је врста штедње која спашава живот и укључује материјалну заштиту појединца од ризика од превремене смрти и губитка или губитка способности за зараду. У условима када је солидарни пензијски систем неодржив, неопходно је развити добровољно пензијско осигурање и штедњу кроз животно осигурање, као изворе дугорочне штедње и додатне изворе финансирања. Предмет овог истраживања је да одговори на питање шта људи мисле о штедњи кроз животно осигурање. Основни циљ овог истраживања је процена односа становника Републике Србије према штедњи кроз животно осигурање. Истраживање је спроведено на територији целе Републике Србије, на одговарајућем узорку од 500 испитаника. Кроз овај рад на једном месту се анализира однос грађана према штедњи кроз животно осигурање у Републици Србији. Анализом података из анкете можемо закључити да се потврђује општа хипотеза: Становници нису задовољни тренутним стањем штедње кроз животно осигурање у Републици Србији.

Corresponding author 
Кључне речи: живот, штедња путем животног осигурања, материјална сигурност, дугорочна штедња, додатни извор финансирања.

JEЛ класификација: G22, G23

\section{Introduction}

The most common type of insurance in the world is life insurance. In 2017, life insurance premiums accounted for about $59 \%$ of the total insurance premiums in the world. In almost every year, in the last three decades, life insurance has grown faster than non-life insurance and this trend is expected to continue in the future (Piljan et al., 2015, p. 99). In Serbia, life insurance today accounts for about $24 \%$ of the total insurance premium. Although it is still insufficient, great progress has been made in the last ten years, since for that time the share of life insurance has had few estimates. The importance of life insurance in Serbia is growing and has great potential to increase in the future.

The basic significance of a life insurance policy is that it represents insurance and savings at the same time. In addition to the function of expanding compulsory (social) insurance, life insurance plays a significant role in every economy because the payment of life insurance premiums accumulates funds that represent long-term, predetermined earmarked savings. Therefore, the policy can be used on the financial market as a security and is an important source of investment, where a significant return is achieved (Piljan et al., 2019, p. 87).

The classic products of life insurance in the event of death are about 250 years old, but similar principles are still used today, on which they were based from the beginning. In the meantime, a large number of life insurance products have been developed and the tendency to develop new products continues (Ćurčić et al., 2019, p. 25).

What affirms life insurers to take an important place in the financial system are their following important characteristics: stable flow of insurance premiums, long-term source of funds, long-term placements, time mismatch of payments and disbursements and predictability of the insured event, i.e. predictability of withdrawal (Piljan et al., 2018, p. 78). Thanks to the long-term source of funds, life insurers form such an investment portfolio which, in the first place, consists of long-term placements that carry long-term returns. Of course, the life insurer's portfolio must be designed to meet liquidity requirements.

\section{Savings through life insurance}

Life insurance savings refers to all insurances in which the termination or duration of life of one or more persons results in the payment of the sum insured by the insurer. These savings can be most simply defined as a contract by which the insurer undertakes to pay a certain amount or annuity to the insured person in the event of death or in the event of his survival, in accordance with the premiums collected from the insured (Marović \& Avdalović, 2006, p. 133). We can also say that saving through life insurance are a specific type of insurance because it is about insuring the risk of death, so it is the most widespread form of insurance 
worldwide (Marković \& Jovanović, 2010, p. 17). There is almost no insurance company in the world that operates in highly developed countries, without offering savings through life insurance in its portfolio as a type of insurance. At the same time, we can say that it is the most attractive form of savings in the world because through individual life insurance, otherwise called savings insurance, almost all the money paid can be returned to you after a few years, and a certain percentage profit is also possible (Gvozdenović \& Uzelac, 2018, p.37). It implies not only savings, but also the payment of compensation if something happens to the insured in the period in which the life insurance was concluded.

In some countries, people who save through life insurance are entitled to tax relief, and with the same policy they can get various loans. When we talk about saving through life insurance, we must not overlook the fact that it is a risk of death that is variable and progressively increases with age (Piljan et al., 2017, p. 395). If we assumed that the amount of the premium should follow the probability of death, which is higher and higher from year to year, we would reach extremely high amounts of premium, which the insured could not bear.

\section{Life insurance in Serbia}

In the current business conditions, the insurance market in Serbia is recording a positive, but relatively slow growth trend. The life insurance market in Serbia, in the last few years, has shown continuous progress, but still lags significantly behind compared to developed European countries (Knežević \& Đurić, 2019, p. 42). The weak development of the life insurance sector is a direct consequence of insufficient economic development, underdevelopment of the financial market, unemployment of the population and inadequate economic reforms. A significant problem is poor education and minimal knowledge of the potential of this type of insurance.

The insurance market in Serbia is relatively stable, with a tendency to grow, but it still faces a number of problems. When it comes to life insurance, its insufficient development is most influenced by the low living standard of the population, unemployment and weak purchasing power, but also inflation and the exchange rate of the domestic currency on which the efficiency of life insurance directly depends (Kostadinović \& Radojičić, 2017, p. 115) These circumstances, with the consequences of the global economic crisis, have led to the fact that the level of life insurance development is still not at the expected level. In the realization of future goals of economic growth and development, life insurance will have a significant role, both in achieving the security of the individual and the role of the institutional investor whose funds are used to finance the development of the state (Vesić et al., 2019, p. 11).

The insurance market in Serbia is in a period of relative stability. Although there is a continuous growth, if the neighboring countries are taken into account, it is noticeable that the entire insurance sector is still underdeveloped and is well below the average of the surrounding countries. Underdevelopment is even more noticeable when compared to European Union countries. 


\section{Examining the attitude of residents}

The aim of the research is to assess the attitude of the inhabitants of the Republic of Serbia regarding the issue of savings through life insurance.

The general hypothesis is: Residents are not satisfied with the current state of savings through life insurance in the Republic of Serbia.

The research was conducted on the territory of the entire Republic of Serbia, on a suitable sample of 500 respondents. The structure of the sample is by gender: $47.6 \% \mathrm{men}$, $52.4 \%$ women; by age: up to 35 years of age $45.6 \%$, over 35 years of age $54.4 \%$; by education: secondary education $37 \%$, basic vocational education $17.6 \%$, university education $24.8 \%$, master's/doctoral degree $20.6 \%$; by length of service: up to 10 years of service $38.8 \%$, from 11 to 20 years of service $32.6 \%$, from 21 to 30 years of service $17 \%$, over 30 years of service $11.6 \%$; according to the position in the company: workers $55.2 \%$, operational level manager $18.4 \%$, mid-level manager $14.6 \%$ and top manager $11.8 \%$.

The statistical method as an general scientific method dominates in the research, and the descriptive $-\neg$ survey-research-method, as a special method. This variant of scientific description implies active involvement of respondents in providing information about the phenomena that are the subject of study, on the basis of which one can enter the essence of the research subject and determine its condition, but also discover causal connections and relationships. The SPSS (Statistical Package for Social Sciences) program was used for statistical data processing. The non-parametric statistical procedure Chi square and the contingency coefficient $\mathrm{C}$ were used for data processing.

Table 1: Life insurance savings are a good form of savings

\begin{tabular}{|c|c|c|c|c|c|c|c|c|}
\hline \multirow{2}{*}{\multicolumn{2}{|c|}{$\begin{array}{l}\text { Socio-andragogical } \\
\text { characteristics of the } \\
\text { respondents }\end{array}$}} & \multicolumn{7}{|c|}{ Life insurance savings are a good form of savings } \\
\hline & & 1 & 2 & 3 & & & $x^{2}$ i C & $\mathrm{p}$ \\
\hline \multirow{4}{*}{ Gender } & \multirow{2}{*}{ 1. Male } & 89 & 52 & 97 & 238 & \multirow{4}{*}{$\begin{array}{c}500 \\
100 \%\end{array}$} & \multirow{4}{*}{$\begin{array}{c}x^{2}=12,574 \\
\mathrm{C}=0,157\end{array}$} & \multirow{4}{*}{$\begin{array}{c}\mathrm{p}=0,002 \\
\mathrm{p}<0,05\end{array}$} \\
\hline & & $17,8 \%$ & $10,4 \%$ & $19,4 \%$ & $47,6 \%$ & & & \\
\hline & \multirow{2}{*}{ 2. Female } & 63 & 55 & 144 & 262 & & & \\
\hline & & $12,6 \%$ & $11,0 \%$ & $28,8 \%$ & $52,4 \%$ & & & \\
\hline \multirow{4}{*}{ Years of life } & \multirow{2}{*}{$\begin{array}{l}\text { 1. Up to } 35 \\
\text { years }\end{array}$} & 54 & 47 & 127 & 228 & \multirow{4}{*}{$\begin{array}{c}500 \\
100 \%\end{array}$} & \multirow{4}{*}{$\begin{array}{c}x^{2}=11,233 \\
\mathrm{C}=0,148\end{array}$} & \multirow{4}{*}{$\begin{array}{l}\mathrm{p}=0,004 \\
\mathrm{p}<0,05\end{array}$} \\
\hline & & $10,8 \%$ & $9,4 \%$ & $25,4 \%$ & $45,6 \%$ & & & \\
\hline & \multirow{2}{*}{$\begin{array}{l}\text { 2. Over } 35 \\
\text { years }\end{array}$} & 98 & 60 & 114 & 272 & & & \\
\hline & & $19,6 \%$ & $12,0 \%$ & $22,8 \%$ & $54,4 \%$ & & & \\
\hline \multirow{8}{*}{$\begin{array}{l}\text { Professional } \\
\text { qualifications }\end{array}$} & \multirow{2}{*}{$\begin{array}{l}\text { 1.Secondary } \\
\text { education }\end{array}$} & 51 & 46 & 88 & 185 & \multirow{8}{*}{$\begin{array}{c}500 \\
100 \%\end{array}$} & \multirow{8}{*}{$\begin{aligned} x^{2} & =6,035 \\
C & =0,109\end{aligned}$} & \multirow{8}{*}{$\begin{array}{c}\mathrm{p}=0,419 \\
\mathrm{p}>0,05\end{array}$} \\
\hline & & $10,2 \%$ & $9,2 \%$ & $17,6 \%$ & $37,0 \%$ & & & \\
\hline & 2. Basic & 30 & 12 & 46 & 88 & & & \\
\hline & $\begin{array}{l}\text { vocational } \\
\text { education }\end{array}$ & $6,0 \%$ & $2,4 \%$ & $9,2 \%$ & $17,6 \%$ & & & \\
\hline & 3.University & 35 & 28 & 61 & 124 & & & \\
\hline & education & $7,0 \%$ & $5,6 \%$ & $12,2 \%$ & $24,8 \%$ & & & \\
\hline & \multirow{2}{*}{$\begin{array}{l}\text { 4. Master's } \\
\text { /Doctoral } \\
\text { degree }\end{array}$} & 36 & 21 & 46 & 103 & & & \\
\hline & & $7,2 \%$ & $4,2 \%$ & $9,2 \%$ & $20,6 \%$ & & & \\
\hline \multirow{2}{*}{$\begin{array}{l}\text { Years of } \\
\text { service }\end{array}$} & \multirow{2}{*}{$\begin{array}{l}\text { 1. Up to } 10 \\
\text { years }\end{array}$} & 49 & 37 & 108 & 194 & \multirow{2}{*}{$\begin{array}{c}500 \\
100 \%\end{array}$} & $x^{2}=16,811$ & \multirow{2}{*}{$\begin{array}{c}\mathrm{p}=0,010 \\
\mathrm{p}<0,05\end{array}$} \\
\hline & & $9,8 \%$ & $7,4 \%$ & $21,6 \%$ & $38,8 \%$ & & $\mathrm{C}=0,180$ & \\
\hline
\end{tabular}




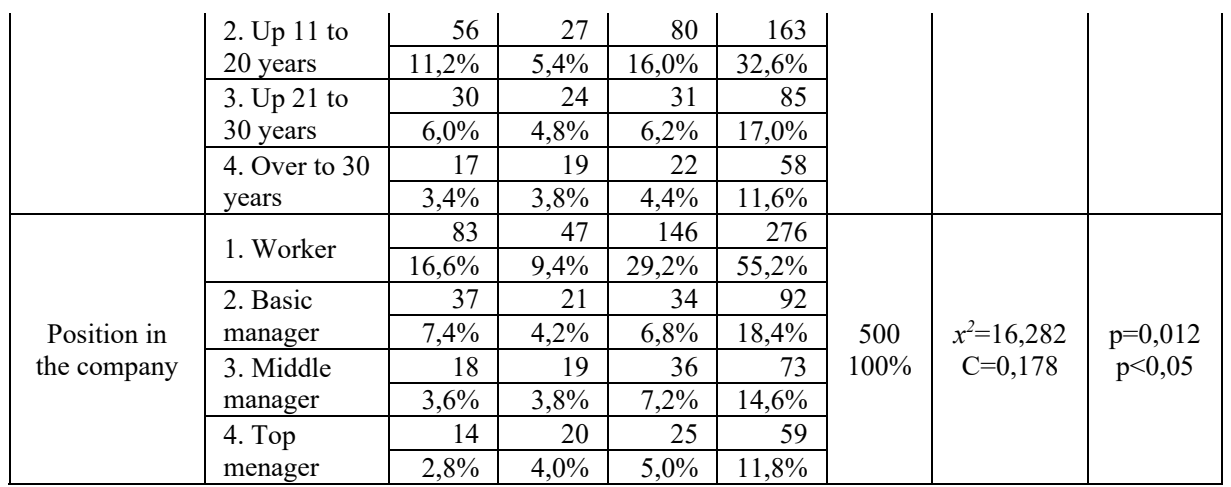

Source: the authors' research

Figure 1: Agreement with the statement: Life insurance savings are a good form of savings

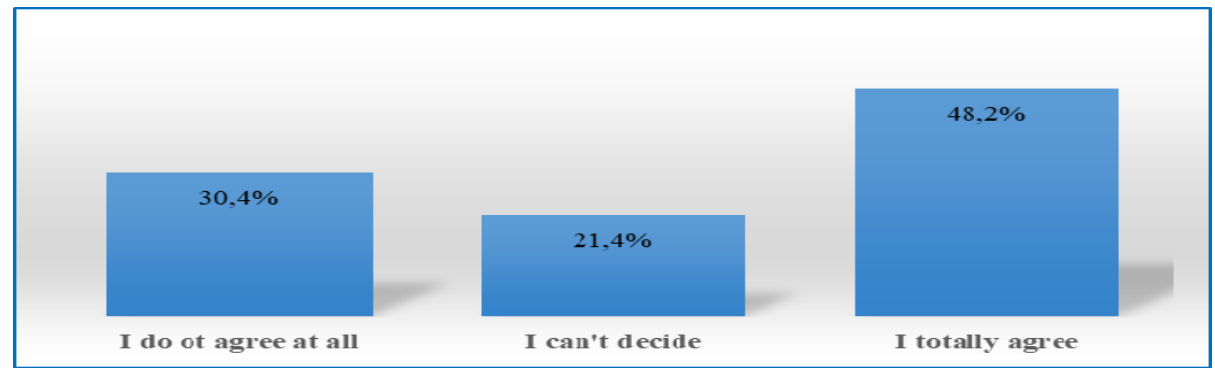

Source: Authors research

Research shows that the independent variable education is not significantly related to respondents' attitudes about life insurance savings. Namely, the value of the Chi square test and the contingency coefficient $C$ shows $\left(x^{2}=6,035 C=0.109\right.$ and $\left.p=0.419\right)$ that the length of service is not statistically significantly related to the stated attitude of the respondents, while this is not the case when it comes to gender, age, work experience and position in the company most respondents agree with the view that saving through life insurance is a good form of saving, but we have differences in attitudes. When it comes to life insurance, the young generation attaches significantly more importance and has more confidence in the data. It is certain that the respondents and labor organizations cannot solve this issue on their own, and the maximum involvement of all state apparatuses is expected in resolving this issue. This attitude of the young generation may be expected. This is exactly the period of life when you should think about solving the problem of pension insurance as much as possible.

In the second question as well, not all independent variables are statistically significantly related to the attitudes of the respondents that savings through life insurance are not sufficiently developed in our country. The value of the Chi square test and the contingency coefficient $\mathrm{C}$ show that the gender, age, education, work experience and position of the respondents in the company are not statistically significantly related to the stated attitude of the respondents. 
Table 2: Savings through life insurance are not sufficiently developed in our country

\begin{tabular}{|c|c|c|c|c|c|c|c|c|}
\hline \multirow{2}{*}{\multicolumn{2}{|c|}{$\begin{array}{l}\text { Socio-andragogical } \\
\text { characteristics of the } \\
\text { respondents }\end{array}$}} & \multicolumn{7}{|c|}{ Savings through life insurance are not sufficiently developed in our country } \\
\hline & & 1 & 2 & 3 & & & $x^{2}$ i C & $\mathrm{p}$ \\
\hline \multirow{4}{*}{ Gender } & \multirow{2}{*}{ 1. Male } & 9 & 29 & 200 & 238 & \multirow{4}{*}{$\begin{array}{c}500 \\
100 \%\end{array}$} & \multirow{4}{*}{$\begin{array}{l}x^{2}=1,854 \\
\mathrm{C}=0,061\end{array}$} & \multirow{4}{*}{$\begin{array}{c}\mathrm{p}=0,396 \\
\mathrm{p}>0,05\end{array}$} \\
\hline & & $1,8 \%$ & $5,8 \%$ & $40,0 \%$ & $47,6 \%$ & & & \\
\hline & \multirow{2}{*}{ 2. Female } & 17 & 31 & 214 & 262 & & & \\
\hline & & $3,4 \%$ & $6,2 \%$ & $42,8 \%$ & $52,4 \%$ & & & \\
\hline \multirow{4}{*}{ Years of life } & \multirow{2}{*}{$\begin{array}{l}\text { 1. Up to } 35 \\
\text { years }\end{array}$} & 11 & 29 & 188 & 228 & \multirow{4}{*}{$\begin{array}{c}500 \\
100 \%\end{array}$} & \multirow{4}{*}{$\begin{array}{l}x^{2}=0,300 \\
\mathrm{C}=0,024\end{array}$} & \multirow{4}{*}{$\begin{array}{c}\mathrm{p}=0,861 \\
\mathrm{p}>0,05\end{array}$} \\
\hline & & $2,2 \%$ & $5,8 \%$ & $37,6 \%$ & $45,6 \%$ & & & \\
\hline & \multirow{2}{*}{$\begin{array}{l}\text { 2. Over } 35 \\
\text { years }\end{array}$} & 15 & 31 & 226 & 272 & & & \\
\hline & & $3,0 \%$ & $6,2 \%$ & $45,2 \%$ & $54,4 \%$ & & & \\
\hline \multirow{8}{*}{$\begin{array}{l}\text { Professional } \\
\text { qualifications }\end{array}$} & \multirow{2}{*}{$\begin{array}{l}\text { 1.Secondary } \\
\text { education }\end{array}$} & 12 & 21 & 152 & 185 & \multirow{8}{*}{$\begin{array}{c}500 \\
100 \%\end{array}$} & \multirow{8}{*}{$\begin{array}{l}\mathrm{x}^{2}=6,022 \\
\mathrm{C}=0,109\end{array}$} & \multirow{8}{*}{$\begin{array}{c}\mathrm{p}=0,421 \\
\mathrm{p}>0,05\end{array}$} \\
\hline & & $2,4 \%$ & $4,2 \%$ & $30,4 \%$ & $37,0 \%$ & & & \\
\hline & 2. Basic & 7 & 14 & 67 & 88 & & & \\
\hline & education & $1,4 \%$ & $2,8 \%$ & $13,4 \%$ & $17,6 \%$ & & & \\
\hline & \multirow{2}{*}{$\begin{array}{l}\text { 3.University } \\
\text { education }\end{array}$} & 4 & 13 & 107 & 124 & & & \\
\hline & & $0,8 \%$ & $2,6 \%$ & $21,4 \%$ & $24,8 \%$ & & & \\
\hline & \multirow{2}{*}{$\begin{array}{l}\text { 4. Master's } \\
\text { /Doctoral } \\
\text { degree }\end{array}$} & 3 & 12 & 88 & 103 & & & \\
\hline & & $0,6 \%$ & $2,4 \%$ & $17,6 \%$ & $20,6 \%$ & & & \\
\hline \multirow{8}{*}{$\begin{array}{l}\text { Years of } \\
\text { service }\end{array}$} & \multirow{2}{*}{$\begin{array}{l}\text { 1. Up tu } 10 \\
\text { years }\end{array}$} & 6 & 28 & 160 & 194 & \multirow{8}{*}{$\begin{array}{c}500 \\
100 \%\end{array}$} & \multirow{8}{*}{$\begin{array}{l}x^{2}=7,177 \\
\mathrm{C}=0,119\end{array}$} & \multirow{8}{*}{$\begin{array}{c}\mathrm{p}=0,305 \\
\mathrm{p}>0,05\end{array}$} \\
\hline & & $1,2 \%$ & $5,6 \%$ & $32,0 \%$ & $38,8 \%$ & & & \\
\hline & 2. Up 11 to & 8 & 16 & 139 & 163 & & & \\
\hline & 20 years & $1,6 \%$ & $3,2 \%$ & $27,8 \%$ & $32,6 \%$ & & & \\
\hline & 3. $\mathrm{Up} 21$ to & 6 & 10 & 69 & 85 & & & \\
\hline & 30 years & $1,2 \%$ & $2,0 \%$ & $13,8 \%$ & $17,0 \%$ & & & \\
\hline & \multirow{2}{*}{$\begin{array}{l}\text { 4. Over to } 30 \\
\text { years }\end{array}$} & 6 & 6 & 46 & 58 & & & \\
\hline & & $1,2 \%$ & $1,2 \%$ & $9,2 \%$ & $11,6 \%$ & & & \\
\hline \multirow{8}{*}{$\begin{array}{l}\text { Position in the } \\
\text { company }\end{array}$} & 1. W/ror & 10 & 38 & 228 & 276 & & & \\
\hline & 1. WOIKCI & $2,0 \%$ & $7,6 \%$ & $45,6 \%$ & $55,2 \%$ & & & \\
\hline & 2. Basic & 7 & 8 & 77 & 92 & & & \\
\hline & manager & $1,4 \%$ & $1,6 \%$ & $15,4 \%$ & $18,4 \%$ & 500 & $x^{2}=6,203$ & $\mathrm{p}=0,401$ \\
\hline & 3. Middle & 6 & 6 & 61 & 73 & $100 \%$ & $\mathrm{C}=0,111$ & $\mathrm{p}>0,05$ \\
\hline & manager & $1,2 \%$ & $1,2 \%$ & $12,2 \%$ & $14,6 \%$ & & & \\
\hline & 4. Top & 3 & 8 & 48 & 59 & & & \\
\hline & menager & $0,6 \%$ & $1,6 \%$ & $9,6 \%$ & $11,8 \%$ & & & \\
\hline
\end{tabular}

Source: the authors' research

This means that we do not have significant deviations regarding the mentioned position. 


\section{Empirical study of savings through life insurance in the Republic of Serbia}

Figure 2: Agreement with the statement: Savings through life insurance are not sufficiently developed in our country

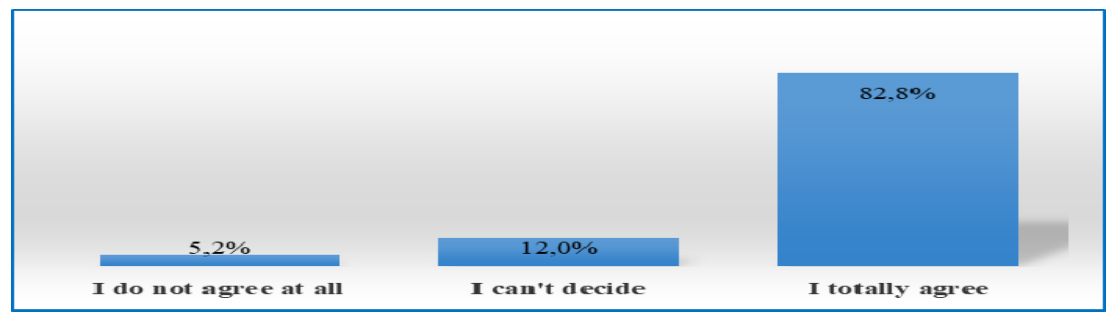

Source: the authors' research

The conclusion is that regardless of age, gender, education, work experience and position in the company, most respondents agree with the view that savings through life insurance in our country are underdeveloped.

Table 3: Conditions for the development of savings through life insurance in our country are not favorable

\begin{tabular}{|c|c|c|c|c|c|c|c|c|}
\hline \multirow{2}{*}{\multicolumn{2}{|c|}{$\begin{array}{l}\text { Socio-andragogical } \\
\text { characteristics of the } \\
\text { respondents }\end{array}$}} & \multicolumn{7}{|c|}{$\begin{array}{l}\text { Conditions for the development of savings through life insurance in } \\
\text { our country are not favorable }\end{array}$} \\
\hline & & 1 & 2 & 3 & In & & $x^{2} \mathrm{iC}$ & $\mathrm{p}$ \\
\hline \multirow{4}{*}{ Gender } & \multirow{2}{*}{ 1. Male } & 20 & 59 & 159 & 238 & \multirow{4}{*}{$\begin{array}{c}500 \\
100 \%\end{array}$} & \multirow{4}{*}{$\begin{array}{l}x^{2}=1,022 \\
\mathrm{C}=0,045\end{array}$} & \multirow{4}{*}{$\begin{array}{c}\mathrm{p}=0,600 \\
\mathrm{p}>0,05\end{array}$} \\
\hline & & $4,0 \%$ & $11,8 \%$ & $31,8 \%$ & $47,6 \%$ & & & \\
\hline & \multirow{2}{*}{ 2. Female } & 23 & 55 & 184 & 262 & & & \\
\hline & & $4,6 \%$ & $11,0 \%$ & $36,8 \%$ & $52,4 \%$ & & & \\
\hline \multirow{4}{*}{ Years of life } & 1. Up to 35 & 20 & 55 & 153 & 228 & \multirow{4}{*}{$\begin{array}{c}500 \\
100 \%\end{array}$} & \multirow{4}{*}{$\begin{array}{l}x^{2}=0,473 \\
\mathrm{C}=0,031\end{array}$} & \multirow{4}{*}{$\begin{array}{c}\mathrm{p}=0,790 \\
\mathrm{p}>0,05\end{array}$} \\
\hline & years & $4,0 \%$ & $11,0 \%$ & $30,6 \%$ & $45,6 \%$ & & & \\
\hline & \multirow{2}{*}{$\begin{array}{l}\text { 2. Over } 35 \\
\text { years }\end{array}$} & 23 & 59 & 190 & 272 & & & \\
\hline & & $4,6 \%$ & $11,8 \%$ & $38,0 \%$ & $54,4 \%$ & & & \\
\hline \multirow{8}{*}{$\begin{array}{l}\text { Professional } \\
\text { qualifications }\end{array}$} & \multirow{2}{*}{$\begin{array}{l}\text { 1.Secondary } \\
\text { education }\end{array}$} & 15 & 43 & 127 & 185 & \multirow{8}{*}{$\begin{array}{c}500 \\
100 \%\end{array}$} & \multirow{8}{*}{$\begin{array}{l}x^{2}=8,963 \\
C=0,133\end{array}$} & \multirow{8}{*}{$\begin{array}{c}\mathrm{p}=0,176 \\
\mathrm{p}>0,05\end{array}$} \\
\hline & & $3,0 \%$ & $8,6 \%$ & $25,4 \%$ & $37,0 \%$ & & & \\
\hline & 2. Basic & 11 & 18 & 59 & 88 & & & \\
\hline & $\begin{array}{l}\text { vocational } \\
\text { education }\end{array}$ & $2,2 \%$ & $3,6 \%$ & $11,8 \%$ & $17,6 \%$ & & & \\
\hline & 3.University & 5 & 35 & 84 & 124 & & & \\
\hline & education & $1,0 \%$ & $7,0 \%$ & $16,8 \%$ & $24,8 \%$ & & & \\
\hline & \multirow{2}{*}{$\begin{array}{l}\text { 4. Master's } \\
\text { /Doctoral } \\
\text { degree }\end{array}$} & 12 & 18 & 73 & 103 & & & \\
\hline & & $2,4 \%$ & $3,6 \%$ & $14,6 \%$ & $20,6 \%$ & & & \\
\hline \multirow{8}{*}{$\begin{array}{l}\text { Years of } \\
\text { service }\end{array}$} & \multirow{2}{*}{$\begin{array}{l}\text { 1. Up tu } 10 \\
\text { years }\end{array}$} & 18 & 47 & 129 & 194 & \multirow{8}{*}{$\begin{array}{c}500 \\
100 \%\end{array}$} & \multirow{8}{*}{$\begin{array}{l}x^{2}=1,569 \\
\mathrm{C}=0,056\end{array}$} & \multirow{8}{*}{$\begin{array}{c}\mathrm{p}=0,955 \\
\mathrm{p}>0,05\end{array}$} \\
\hline & & $3,6 \%$ & $9,4 \%$ & $25,8 \%$ & $38,8 \%$ & & & \\
\hline & 2. Up 11 to & 13 & 37 & 113 & 163 & & & \\
\hline & 20 years & $2,6 \%$ & $7,4 \%$ & $22,6 \%$ & $32,6 \%$ & & & \\
\hline & 3. Up 21 to & 7 & 20 & 58 & 85 & & & \\
\hline & 30 years & $1,4 \%$ & $4,0 \%$ & $11,6 \%$ & $17,0 \%$ & & & \\
\hline & \multirow{2}{*}{$\begin{array}{l}\text { 4. Over to } \\
30 \text { years }\end{array}$} & 5 & 10 & 43 & 58 & & & \\
\hline & & $1,0 \%$ & $2,0 \%$ & $8,6 \%$ & $11,6 \%$ & & & \\
\hline \multirow{5}{*}{$\begin{array}{l}\text { Position in } \\
\text { the company }\end{array}$} & 1 Worker & 24 & 69 & 183 & 276 & \multirow{5}{*}{$\begin{array}{c}500 \\
100 \%\end{array}$} & \multirow{5}{*}{$\begin{array}{l}x^{2}=9,754 \\
\mathrm{C}=0,138\end{array}$} & \multirow{5}{*}{$\begin{array}{c}\mathrm{p}=0,135 \\
\mathrm{p}>0,05\end{array}$} \\
\hline & 1. Worker & $4,8 \%$ & $13,8 \%$ & $36,6 \%$ & $55,2 \%$ & & & \\
\hline & 2. Basic & 13 & 21 & 58 & 92 & & & \\
\hline & manager & $2,6 \%$ & $4,2 \%$ & $11,6 \%$ & $18,4 \%$ & & & \\
\hline & 3. Middle & 3 & 13 & 57 & 73 & & & \\
\hline
\end{tabular}




\begin{tabular}{|l|l|r|r|r|r|l|l|l|}
\cline { 2 - 5 } & manager & $0,6 \%$ & $2,6 \%$ & $11,4 \%$ & $14,6 \%$ & & & \\
\cline { 2 - 6 } $\begin{array}{l}4 . \text { Top } \\
\text { menager }\end{array}$ & 3 & 11 & 45 & 59 & & & \\
\cline { 2 - 7 } & $0,6 \%$ & $2,2 \%$ & $9,0 \%$ & $11,8 \%$ & & & \\
\hline
\end{tabular}

Source: the authors' research

Figure 3: Agreement with the statement: The conditions for the development of savings through life insurance in our country are not favorable

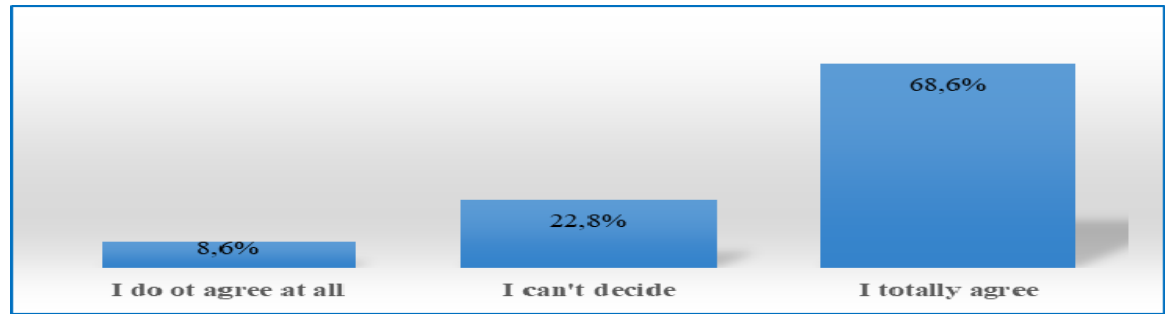

Source: the authors' research

As in the previous case, the analysis of the data in Table 3, shows that not all independent variables are statistically significantly related to the respondents' opinions about the conditions for the development of life insurance. The value of the Chi square test and the contingency coefficient $\mathrm{C}$ show that the gender, age, education, work experience and position of the respondents in the company are not statistically significantly related to the stated attitude of the respondents. This means that we do not have significant deviations regarding the mentioned position. Based on the data from the table, we can conclude that regardless of gender, age, education, work experience and position in the company, most respondents agree with the view that the conditions for the development of savings through life insurance in our country are not favorable.

Table 4: I don't trust saving through life insurance

\begin{tabular}{|c|c|c|c|c|c|c|c|c|}
\hline \multirow{2}{*}{\multicolumn{2}{|c|}{$\begin{array}{l}\text { Socio-andragogical } \\
\text { characteristics of the } \\
\text { respondents }\end{array}$}} & \multicolumn{7}{|c|}{ I don't trust saving through life insurance } \\
\hline & & 1 & 2 & 3 & & & $x^{2}$ i C & $\mathrm{p}$ \\
\hline \multirow{4}{*}{ Gender } & \multirow{2}{*}{ 1. Male } & 58 & 82 & 98 & 238 & \multirow{4}{*}{$\begin{array}{c}500 \\
100 \%\end{array}$} & \multirow{4}{*}{$\begin{array}{l}x^{2}=1,368 \\
\mathrm{C}=0,052\end{array}$} & \multirow{4}{*}{$\begin{array}{c}\mathrm{p}=0,505 \\
\mathrm{p}>0,05\end{array}$} \\
\hline & & $11,6 \%$ & $16,4 \%$ & $19,6 \%$ & $47,6 \%$ & & & \\
\hline & \multirow{2}{*}{ 2. Female } & 76 & 85 & 101 & 262 & & & \\
\hline & & $15,2 \%$ & $17,0 \%$ & $20,2 \%$ & $52,4 \%$ & & & \\
\hline \multirow{4}{*}{ Years of life } & 1. Up to 35 & 58 & 78 & 92 & 228 & \multirow{4}{*}{$\begin{array}{c}500 \\
100 \%\end{array}$} & \multirow{4}{*}{$\begin{array}{l}x^{2}=0,404 \\
C=0,028\end{array}$} & \multirow{4}{*}{$\begin{array}{c}\mathrm{p}=0,817 \\
\mathrm{p}>0,05\end{array}$} \\
\hline & years & $11,6 \%$ & $15,6 \%$ & $18,4 \%$ & $45,6 \%$ & & & \\
\hline & \multirow{2}{*}{$\begin{array}{l}\text { 2. Over } 35 \\
\text { years }\end{array}$} & 76 & 89 & 107 & 272 & & & \\
\hline & & $15,2 \%$ & $17,8 \%$ & $21,4 \%$ & $54,4 \%$ & & & \\
\hline \multirow{8}{*}{$\begin{array}{c}\text { Professional } \\
\text { qualifications }\end{array}$} & \multirow{2}{*}{$\begin{array}{l}\text { 1.Secondary } \\
\text { education }\end{array}$} & 64 & 56 & 65 & 185 & \multirow{8}{*}{$\begin{array}{c}500 \\
100 \%\end{array}$} & \multirow{8}{*}{$\begin{array}{c}\mathrm{x}^{2}=22,189 \\
\mathrm{C}=0,206\end{array}$} & \multirow{8}{*}{$\begin{array}{l}\mathrm{p}=0,001 \\
\mathrm{p}<0,05\end{array}$} \\
\hline & & $12,8 \%$ & $11,2 \%$ & $13,0 \%$ & $37,0 \%$ & & & \\
\hline & 2. Basic & 20 & 27 & 41 & 88 & & & \\
\hline & $\begin{array}{l}\text { vocational } \\
\text { education }\end{array}$ & $4,0 \%$ & $5,4 \%$ & $8,2 \%$ & $17,6 \%$ & & & \\
\hline & \multirow{2}{*}{$\begin{array}{l}\text { 3.University } \\
\text { education }\end{array}$} & 27 & 57 & 40 & 124 & & & \\
\hline & & $5,4 \%$ & $11,4 \%$ & $8,0 \%$ & $24,8 \%$ & & & \\
\hline & \multirow{2}{*}{$\begin{array}{l}\text { 4. Master's } \\
\text { /Doctoral } \\
\text { degree }\end{array}$} & 23 & 27 & 53 & 103 & & & \\
\hline & & $4,6 \%$ & $5,4 \%$ & $10,6 \%$ & $20,6 \%$ & & & \\
\hline
\end{tabular}




\begin{tabular}{|c|c|c|c|c|c|c|c|c|}
\hline \multirow{8}{*}{$\begin{array}{l}\text { Years of } \\
\text { service }\end{array}$} & \multirow{2}{*}{$\begin{array}{l}\text { 1. Up tu } 10 \\
\text { years }\end{array}$} & 54 & 55 & 85 & 194 & \multirow{8}{*}{$\begin{array}{c}500 \\
100 \%\end{array}$} & \multirow{8}{*}{$\begin{array}{l}x^{2}=9,387 \\
\mathrm{C}=0,136\end{array}$} & \multirow{8}{*}{$\begin{array}{l}\mathrm{p}=0,153 \\
\mathrm{p}>0,05\end{array}$} \\
\hline & & $10,8 \%$ & $11,0 \%$ & $17,0 \%$ & $38,8 \%$ & & & \\
\hline & \multirow{2}{*}{$\begin{array}{l}\text { 2. Up } 11 \text { to } 20 \\
\text { years }\end{array}$} & 42 & 55 & 66 & 163 & & & \\
\hline & & $8,4 \%$ & $11,0 \%$ & $13,2 \%$ & $32,6 \%$ & & & \\
\hline & \multirow{2}{*}{$\begin{array}{l}\text { 3. Up } 21 \text { to } 30 \\
\text { years }\end{array}$} & 18 & 38 & 29 & 85 & & & \\
\hline & & $3,6 \%$ & $7,6 \%$ & $5,8 \%$ & $17,0 \%$ & & & \\
\hline & \multirow{2}{*}{$\begin{array}{l}\text { 4. Over to } 30 \\
\text { years }\end{array}$} & 20 & 19 & 19 & 58 & & & \\
\hline & & $4,0 \%$ & $3,8 \%$ & $3,8 \%$ & $11,6 \%$ & & & \\
\hline \multirow{8}{*}{$\begin{array}{l}\text { Position in the } \\
\text { company }\end{array}$} & \multirow{2}{*}{ 1. Worker } & 75 & 95 & 106 & 276 & \multirow{8}{*}{$\begin{array}{c}500 \\
100 \%\end{array}$} & \multirow{8}{*}{$\begin{array}{l}x^{2}=2,356 \\
\mathrm{C}=0,068\end{array}$} & \multirow{8}{*}{$\begin{array}{l}\mathrm{p}=0,884 \\
\mathrm{p}>0,05\end{array}$} \\
\hline & & $15,0 \%$ & $19,0 \%$ & $21,2 \%$ & $55,2 \%$ & & & \\
\hline & \multirow{2}{*}{$\begin{array}{l}\text { 2. Basic } \\
\text { manager }\end{array}$} & 24 & 26 & 42 & 92 & & & \\
\hline & & $4,8 \%$ & $5,2 \%$ & $8,4 \%$ & $18,4 \%$ & & & \\
\hline & \multirow{2}{*}{$\begin{array}{l}\text { 3. Middle } \\
\text { manager }\end{array}$} & 19 & 24 & 30 & 73 & & & \\
\hline & & $3,8 \%$ & $4,8 \%$ & $6,0 \%$ & $14,6 \%$ & & & \\
\hline & \multirow{2}{*}{$\begin{array}{l}\text { 4. Top } \\
\text { menager }\end{array}$} & 16 & 22 & 21 & 59 & & & \\
\hline & & $3,2 \%$ & $4,4 \%$ & $4,2 \%$ & $11,8 \%$ & & & \\
\hline
\end{tabular}

Source: Authors research

Figure 4: Agreement with the statement: I don't trust saving through life insurance

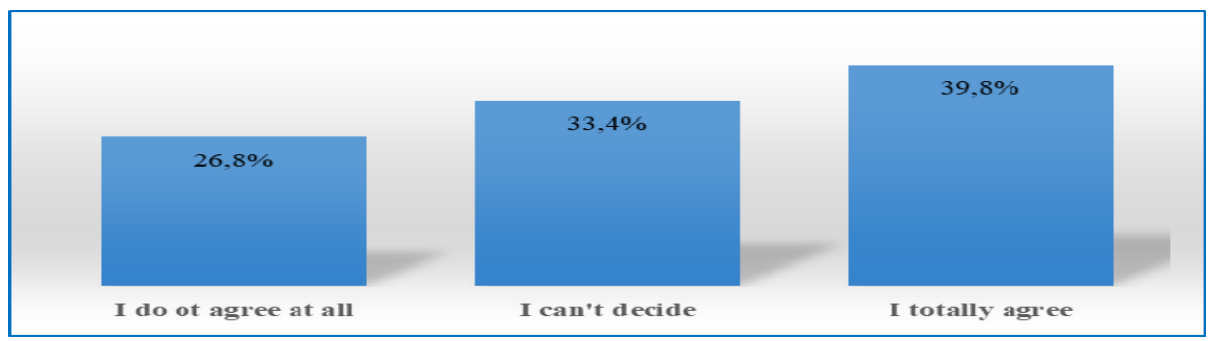

Source: the authors' research

In question no. 4 some independent variables are not statistically significantly related to the respondents' attitudes about trust in life insurance. The value of the Chi square test and the contingency coefficient $\mathrm{C}$ show that gender, age, work experience and position in the company are not statistically significantly related to the stated attitude of the respondents. This means that we do not have significant deviations regarding the mentioned position. Based on the data from the table, we can conclude that regardless of gender, age, work experience and position in the company, most respondents agree with the view that there is no trust in savings through life insurance.

Table 5: The state does not sufficiently support the development of savings through life insurance

\begin{tabular}{|c|c|c|c|c|c|c|c|c|}
\hline \multirow{2}{*}{\multicolumn{2}{|c|}{$\begin{array}{l}\text { Socio-andragogical characteristics } \\
\text { of the respondents }\end{array}$}} & \multicolumn{7}{|c|}{$\begin{array}{l}\text { The state does not sufficiently support the development of savings } \\
\text { through life insurance }\end{array}$} \\
\hline & & 1 & 2 & 3 & & & $x^{2}$ i C & $\mathrm{p}$ \\
\hline \multirow{4}{*}{ Gender } & \multirow{2}{*}{ 1. Male } & 46 & 73 & 119 & 238 & \multirow{4}{*}{$\begin{array}{c}500 \\
100 \%\end{array}$} & \multirow{4}{*}{$\begin{array}{l}x^{2}=5,689 \\
\mathrm{C}=0,047\end{array}$} & \multirow{4}{*}{$\begin{array}{l}\mathrm{p}=0,224 \\
\mathrm{p}>0,05\end{array}$} \\
\hline & & $9,2 \%$ & $14,6 \%$ & $23,8 \%$ & $47,6 \%$ & & & \\
\hline & \multirow{2}{*}{ 2. Female } & 43 & 90 & 129 & 262 & & & \\
\hline & & $8,6 \%$ & $18,0 \%$ & $25,8 \%$ & $52,4 \%$ & & & \\
\hline
\end{tabular}




\begin{tabular}{|c|c|c|c|c|c|c|c|c|}
\hline \multirow{4}{*}{ Years of life } & 1. Up to 35 & 43 & 66 & 119 & 228 & \multirow{4}{*}{$\begin{array}{c}500 \\
100 \%\end{array}$} & \multirow{4}{*}{$\begin{array}{l}x^{2}=2,548 \\
\mathrm{C}=0,071\end{array}$} & \multirow{4}{*}{$\begin{array}{c}p=0,280 \\
p>0,05\end{array}$} \\
\hline & years & $8,6 \%$ & $13,2 \%$ & $23,8 \%$ & $45,6 \%$ & & & \\
\hline & \multirow{2}{*}{$\begin{array}{l}\text { 2. Over } 35 \\
\text { years }\end{array}$} & 46 & 97 & 129 & 272 & & & \\
\hline & & $9,2 \%$ & $19,4 \%$ & $25,8 \%$ & $54,4 \%$ & & & \\
\hline \multirow{8}{*}{$\begin{array}{l}\text { Professional } \\
\text { qualifications }\end{array}$} & \multirow{2}{*}{$\begin{array}{l}\text { 1.Secondary } \\
\text { education }\end{array}$} & 39 & 63 & 83 & 185 & \multirow{8}{*}{$\begin{array}{c}500 \\
100 \%\end{array}$} & \multirow{8}{*}{$\begin{array}{l}x^{2}=6,400 \\
C=0,112\end{array}$} & \multirow{8}{*}{$\begin{array}{c}\mathrm{p}=0,380 \\
\mathrm{p}>0,05\end{array}$} \\
\hline & & $7,8 \%$ & $12,6 \%$ & $16,6 \%$ & $37,0 \%$ & & & \\
\hline & 2. Basic & 16 & 28 & 44 & 88 & & & \\
\hline & education & $3,2 \%$ & $5,6 \%$ & $8,8 \%$ & $17,6 \%$ & & & \\
\hline & \multirow{2}{*}{$\begin{array}{l}\text { 3.University } \\
\text { education }\end{array}$} & 17 & 45 & 62 & 124 & & & \\
\hline & & $3,4 \%$ & $9,0 \%$ & $12,4 \%$ & $24,8 \%$ & & & \\
\hline & \multirow{2}{*}{$\begin{array}{l}\text { 4. Master's } \\
\text { /Doctoral } \\
\text { degree }\end{array}$} & 17 & 27 & 59 & 103 & & & \\
\hline & & $3,4 \%$ & $5,4 \%$ & $11,8 \%$ & $20,6 \%$ & & & \\
\hline \multirow{8}{*}{ Years of service } & \multirow{2}{*}{$\begin{array}{l}\text { 1. Up tu } 10 \\
\text { years }\end{array}$} & 38 & 50 & 106 & 194 & \multirow{8}{*}{$\begin{array}{c}500 \\
100 \%\end{array}$} & \multirow{8}{*}{$\begin{array}{l}x^{2}=9,575 \\
\mathrm{C}=0,137\end{array}$} & \multirow{8}{*}{$\begin{array}{c}\mathrm{p}=0,144 \\
\mathrm{p}>0,05\end{array}$} \\
\hline & & $7,6 \%$ & $10,0 \%$ & $21,2 \%$ & $38,8 \%$ & & & \\
\hline & 2. Up 11 to 20 & 29 & 61 & 73 & 163 & & & \\
\hline & years & $5,8 \%$ & $12,2 \%$ & $14,6 \%$ & $32,6 \%$ & & & \\
\hline & \multirow{2}{*}{$\begin{array}{l}\text { 3. Up } 21 \text { to } 30 \\
\text { years }\end{array}$} & 10 & 34 & 41 & 85 & & & \\
\hline & & $2,0 \%$ & $6,8 \%$ & $8,2 \%$ & $17,0 \%$ & & & \\
\hline & \multirow{2}{*}{$\begin{array}{l}\text { 4. Over to } 30 \\
\text { years }\end{array}$} & 12 & 18 & 28 & 58 & & & \\
\hline & & $2,4 \%$ & $3,6 \%$ & $5,6 \%$ & $11,6 \%$ & & & \\
\hline \multirow{8}{*}{$\begin{array}{l}\text { Position in the } \\
\text { company }\end{array}$} & \multirow{2}{*}{ 1. Worker } & 49 & 92 & 135 & 276 & \multirow{8}{*}{$\begin{array}{c}500 \\
100 \%\end{array}$} & \multirow{8}{*}{$\begin{array}{l}x^{2}=5,855 \\
\mathrm{C}=0,108\end{array}$} & \multirow{8}{*}{$\begin{array}{c}p=0,440 \\
p>0,05\end{array}$} \\
\hline & & $9,8 \%$ & $18,4 \%$ & $27,0 \%$ & $55,2 \%$ & & & \\
\hline & 2. Basic & 14 & 27 & 51 & 92 & & & \\
\hline & manager & $2,8 \%$ & $5,4 \%$ & $10,2 \%$ & $18,4 \%$ & & & \\
\hline & \multirow{2}{*}{$\begin{array}{l}\text { 3. Middle } \\
\text { manager }\end{array}$} & 12 & 21 & 40 & 73 & & & \\
\hline & & $2,4 \%$ & $4,2 \%$ & $8,0 \%$ & $14,6 \%$ & & & \\
\hline & \multirow{2}{*}{ 4. Top menager } & 14 & 23 & 22 & 59 & & & \\
\hline & & $2,8 \%$ & $4,6 \%$ & $4,4 \%$ & $11,8 \%$ & & & \\
\hline
\end{tabular}

Source: the authors' research 
Figure 5: Agreement with the statement: The state does not sufficiently support the development of savings through life insurance

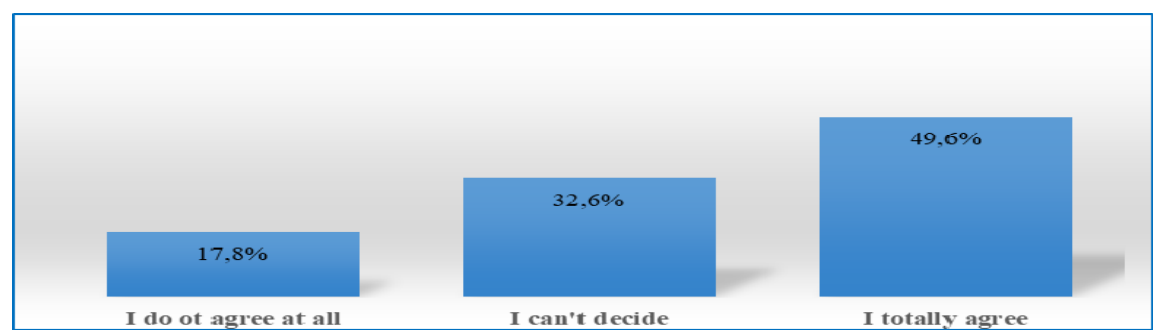

Source: the authors' research

And in question no. 5 not all independent variables are statistically significantly related to the respondents' attitudes that the state does not sufficiently support life insurance savings. The value of the Chi square test and the contingency coefficient $\mathrm{C}$ show that the gender, age, education, work experience and position of the respondents in the company are not statistically significantly related to the stated attitude of the respondents. This means that we do not have significant deviations regarding the mentioned position. Based on the data from the table, we can conclude that regardless of gender, age, education, work experience and position in the company, most respondents agree with the view that the state does not sufficiently support the development of savings through life insurance.

Table 6: Life insurance savings are a necessity of the modern age

\begin{tabular}{|c|c|c|c|c|c|c|c|c|}
\hline \multirow{2}{*}{\multicolumn{2}{|c|}{$\begin{array}{c}\text { Socio-andragogical characteristics } \\
\text { of the respondents }\end{array}$}} & \multicolumn{7}{|c|}{ Life insurance savings are a necessity of the modern age } \\
\hline & & 1 & 3 & 5 & & & $x^{2}$ i C & $\mathrm{p}$ \\
\hline \multirow{4}{*}{ Gender } & \multirow{2}{*}{ 1. Male } & 45 & 79 & 114 & 238 & \multirow{4}{*}{$\begin{array}{c}500 \\
100 \%\end{array}$} & \multirow{4}{*}{$\begin{array}{l}x^{2}=1,292 \\
\mathrm{C}=0,051\end{array}$} & \multirow{4}{*}{$\begin{array}{l}\mathrm{p}=0,524 \\
\mathrm{p}>0,05\end{array}$} \\
\hline & & $9,0 \%$ & $15,8 \%$ & $22,8 \%$ & $47,6 \%$ & & & \\
\hline & \multirow{2}{*}{ 2. Female } & 48 & 76 & 138 & 262 & & & \\
\hline & & $9,6 \%$ & $15,2 \%$ & $27,6 \%$ & $52,4 \%$ & & & \\
\hline \multirow{4}{*}{ Years of life } & 1. Up to 35 & 43 & 64 & 121 & 228 & \multirow{4}{*}{$\begin{array}{c}500 \\
100 \%\end{array}$} & \multirow{4}{*}{$\begin{array}{l}x^{2}=1,769 \\
\mathrm{C}=0,059\end{array}$} & \multirow{4}{*}{$\begin{array}{l}\mathrm{p}=0,413 \\
\mathrm{p}>0,05\end{array}$} \\
\hline & years & $8,6 \%$ & $12,8 \%$ & $24,2 \%$ & $45,6 \%$ & & & \\
\hline & \multirow{2}{*}{$\begin{array}{l}\text { 2. Over } 35 \\
\text { years }\end{array}$} & 50 & 91 & 131 & 272 & & & \\
\hline & & $10,0 \%$ & $18,2 \%$ & $26,2 \%$ & $54,4 \%$ & & & \\
\hline \multirow{8}{*}{$\begin{array}{l}\text { Professional } \\
\text { qualifications }\end{array}$} & \multirow{2}{*}{$\begin{array}{l}\text { 1.Secondary } \\
\text { education }\end{array}$} & 42 & 51 & 92 & 185 & \multirow{8}{*}{$\begin{array}{c}500 \\
100 \%\end{array}$} & \multirow{8}{*}{$\begin{array}{c}\mathrm{x}^{2}=15,230 \\
\mathrm{C}=0,172\end{array}$} & \multirow{8}{*}{$\begin{array}{l}\mathrm{p}=0,019 \\
\mathrm{p}<0,05\end{array}$} \\
\hline & & $8,4 \%$ & $10,2 \%$ & $18,4 \%$ & $37,0 \%$ & & & \\
\hline & 2. Basic & 15 & 34 & 39 & 88 & & & \\
\hline & $\begin{array}{l}\text { vocational } \\
\text { education }\end{array}$ & $3,0 \%$ & $6,8 \%$ & $7,8 \%$ & $17,6 \%$ & & & \\
\hline & \multirow{2}{*}{$\begin{array}{l}\text { 3.University } \\
\text { education }\end{array}$} & 14 & 48 & 62 & 124 & & & \\
\hline & & $2,8 \%$ & $9,6 \%$ & $12,4 \%$ & $24,8 \%$ & & & \\
\hline & \multirow{2}{*}{$\begin{array}{l}\text { 4. Master's } \\
\text { /Doctoral } \\
\text { degree }\end{array}$} & 22 & 22 & 59 & 103 & & & \\
\hline & & $4,4 \%$ & $4,4 \%$ & $11,8 \%$ & $20,6 \%$ & & & \\
\hline \multirow{7}{*}{$\begin{array}{l}\text { Years of } \\
\text { service }\end{array}$} & \multirow{2}{*}{$\begin{array}{l}\text { 1. Up tu } 10 \\
\text { years }\end{array}$} & 37 & 52 & 105 & 194 & \multirow{7}{*}{$\begin{array}{c}500 \\
100 \%\end{array}$} & \multirow{7}{*}{$\begin{array}{c}x^{2}=13,564 \\
\mathrm{C}=0,163\end{array}$} & \multirow{7}{*}{$\begin{array}{l}\mathrm{p}=0,035 \\
\mathrm{p}<0,05\end{array}$} \\
\hline & & $7,4 \%$ & $10,4 \%$ & $21,0 \%$ & $38,8 \%$ & & & \\
\hline & \multirow{2}{*}{$\begin{array}{l}\text { 2. Up } 11 \text { to } 20 \\
\text { years }\end{array}$} & 33 & 57 & 73 & 163 & & & \\
\hline & & $6,6 \%$ & $11,4 \%$ & $14,6 \%$ & $32,6 \%$ & & & \\
\hline & \multirow{2}{*}{$\begin{array}{l}\text { 3. Up } 21 \text { to } 30 \\
\text { years }\end{array}$} & 8 & 34 & 43 & 85 & & & \\
\hline & & $1,6 \%$ & $6,8 \%$ & $8,6 \%$ & $17,0 \%$ & & & \\
\hline & 4. Over to 30 & 15 & 12 & 31 & 58 & & & \\
\hline
\end{tabular}




\begin{tabular}{|c|c|c|c|c|c|c|c|c|}
\hline & years & $3,0 \%$ & $2,4 \%$ & $6,2 \%$ & $11,6 \%$ & & & \\
\hline \multirow{8}{*}{$\begin{array}{l}\text { Position in the } \\
\text { company }\end{array}$} & \multirow{2}{*}{ 1. Worker } & 56 & 82 & 138 & 276 & \multirow{8}{*}{$\begin{array}{c}500 \\
100 \%\end{array}$} & \multirow{8}{*}{$\begin{aligned} x^{2} & =9,456 \\
\mathrm{C} & =0,135\end{aligned}$} & \multirow{8}{*}{$\begin{array}{c}\mathrm{p}=0,150 \\
\mathrm{p}>0,05\end{array}$} \\
\hline & & $11,2 \%$ & $16,4 \%$ & $27,6 \%$ & $55,2 \%$ & & & \\
\hline & \multirow{2}{*}{$\begin{array}{l}\text { 2. Basic } \\
\text { manager }\end{array}$} & 15 & 27 & 50 & 92 & & & \\
\hline & & $3,0 \%$ & $5,4 \%$ & $10,0 \%$ & $18,4 \%$ & & & \\
\hline & \multirow{2}{*}{$\begin{array}{l}\text { 3. Middle } \\
\text { manager }\end{array}$} & 7 & 24 & 42 & 73 & & & \\
\hline & & $1,4 \%$ & $4,8 \%$ & $8,4 \%$ & $14,6 \%$ & & & \\
\hline & \multirow{2}{*}{$\begin{array}{l}\text { 4. Top } \\
\text { menager }\end{array}$} & 15 & 22 & 22 & 59 & & & \\
\hline & & $3,0 \%$ & $4,4 \%$ & $4,4 \%$ & $11,8 \%$ & & & \\
\hline
\end{tabular}

Source: the authors' research

Figure 6: Agreement with the statement: Life insurance savings are a necessity of the modern age

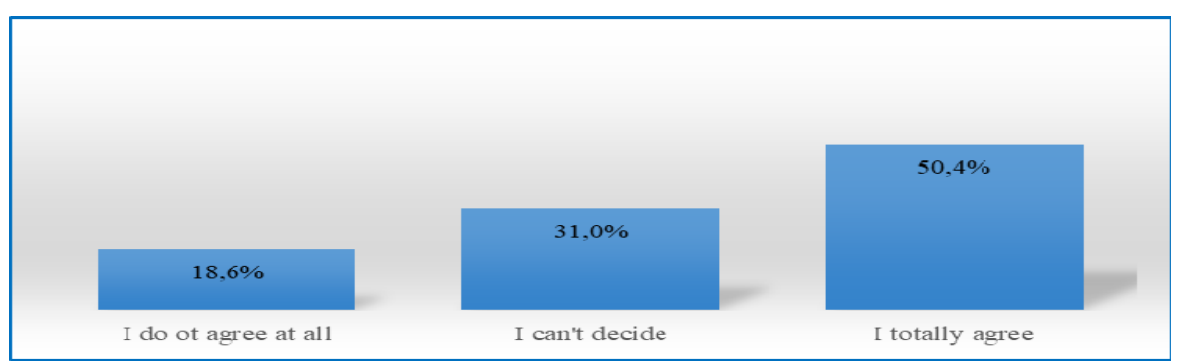

Source: the authors' research

By analyzing the data in Table 6, we can see that some independent variables are not statistically significantly related to the respondents' opinion that saving through life insurance is a necessity of the modern age. The value of the Chi square test and the contingency coefficient $\mathrm{C}$ show that the gender, age and position of the respondents in the company are not statistically significantly related to the stated attitude of the respondents. This means that we do not have significant deviations regarding the mentioned position. Based on the data from the table, we can conclude that regardless of gender, age and position in the company, most respondents agree with the view that saving through life insurance is a necessity of the modern age. When it comes to education and work experience, we have deviations in agreeing with the mentioned position. Among respondents with secondary education and workers, the more dominant view is that saving through life insurance is a necessity of the modern age.

Table 7: I don't have enough money savings through life insurance

\begin{tabular}{|c|c|c|c|c|c|c|c|c|}
\hline \multirow{2}{*}{\multicolumn{2}{|c|}{$\begin{array}{l}\text { Socio-andragogical } \\
\text { characteristics of the respondents }\end{array}$}} & \multicolumn{7}{|c|}{ I don't have enough money savings through life insurance } \\
\hline & & 1 & 3 & 5 & & & $x^{2} \mathrm{i} \mathrm{C}$ & $\mathrm{p}$ \\
\hline \multirow{4}{*}{ Gender } & \multirow{2}{*}{ 1. Male } & 57 & 70 & 111 & 238 & \multirow{4}{*}{$\begin{array}{c}500 \\
100 \%\end{array}$} & \multirow{4}{*}{$\begin{aligned} x^{2} & =2,588 \\
C & =0,071\end{aligned}$} & \multirow{4}{*}{$\begin{array}{l}p=0,278 \\
p>0,05\end{array}$} \\
\hline & & $11,4 \%$ & $14,0 \%$ & $22,2 \%$ & $47,6 \%$ & & & \\
\hline & \multirow{2}{*}{ 2. Female } & 49 & 75 & 138 & 262 & & & \\
\hline & & $9,8 \%$ & $15,0 \%$ & $27,6 \%$ & $52,4 \%$ & & & \\
\hline \multirow{2}{*}{ Years of life } & \multirow{2}{*}{$\begin{array}{l}\text { 1. Up to } 35 \\
\text { years }\end{array}$} & 50 & 67 & 111 & 228 & \multirow{2}{*}{$\begin{array}{c}500 \\
100 \%\end{array}$} & \multirow{2}{*}{$\begin{array}{l}x^{2}=0,232 \\
\mathrm{C}=0,022\end{array}$} & \multirow{2}{*}{$\begin{array}{l}\mathrm{p}=0,891 \\
\mathrm{p}>0,05\end{array}$} \\
\hline & & $10,0 \%$ & $13,4 \%$ & $22,2 \%$ & $45,6 \%$ & & & \\
\hline
\end{tabular}




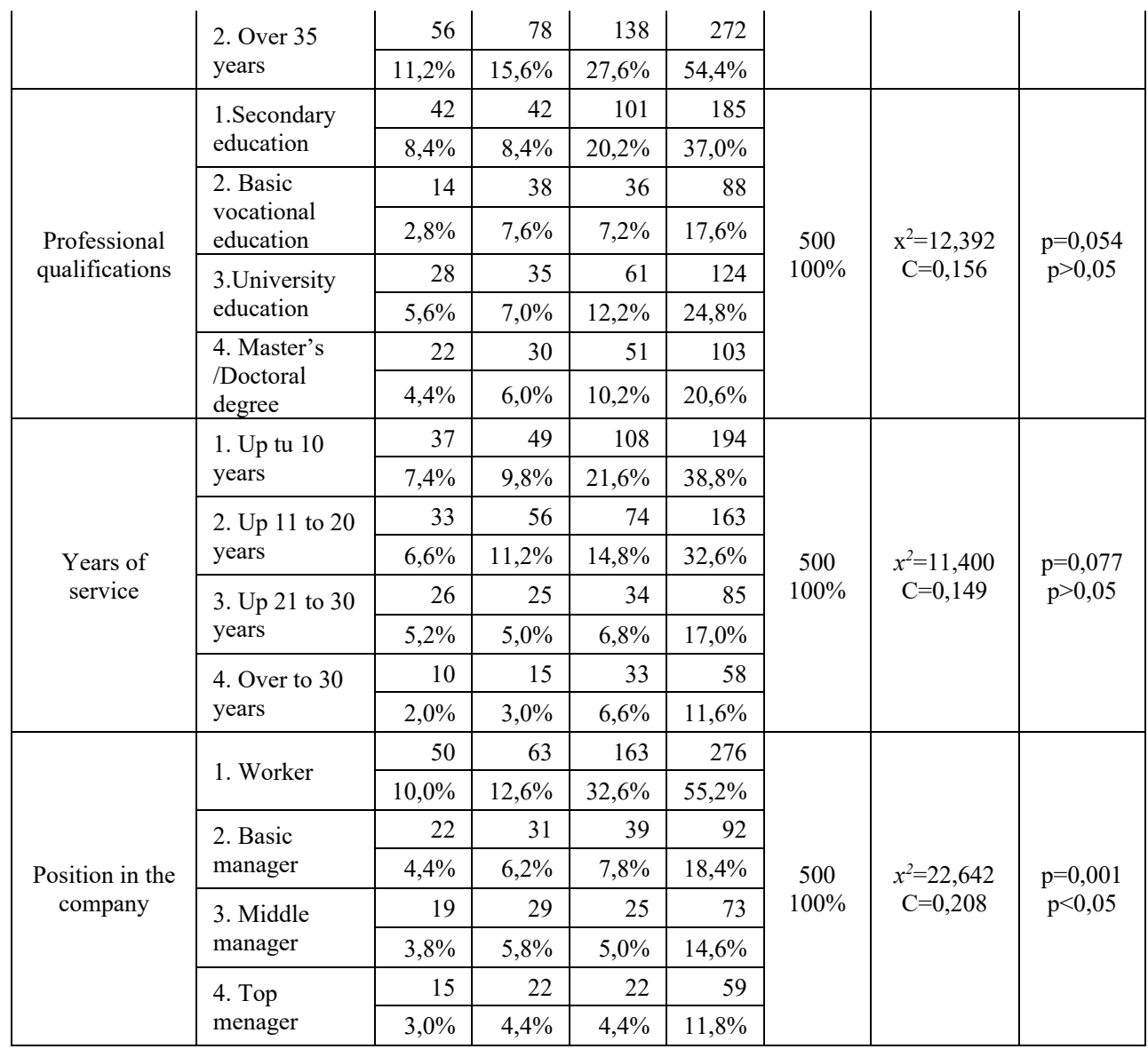

Source: Authors research

Figure 7: Agreement with the statement: I don't have enough money savings through life insurance

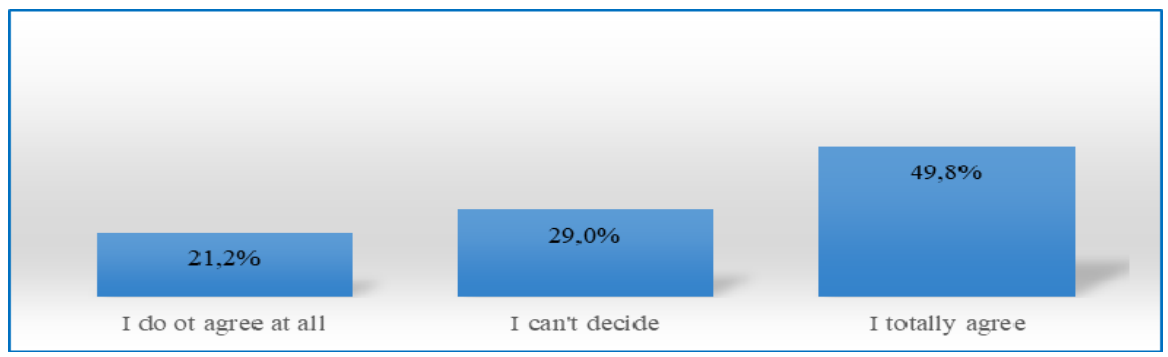

Source: the authors' research

The situation is the same with question no.7 where all independent variables are not statistically significantly related to the attitude of respondents that they do not have enough 
money to invest in savings through life insurance. The value of the Chi square test and the contingency coefficient $\mathrm{C}$ show that gender, age, education and work experience are not statistically significantly related to the stated opinion of the respondents. This means that we do not have significant deviations regarding the mentioned position. Based on the data from the table, we can conclude that regardless of gender, age, education and work experience, most respondents do not agree with the view that there is not enough money savings through life insurance. When it comes to the position in the company, we have that the attitude of the workers differs from the attitude of the manager. Their more dominant attitude is that they do not have enough money to save through life insurance, which is understandably similar to their income.

\section{Conclusion}

Life insurance savings are the subject of discussion and analysis in almost all countries of the world because stable savings are one of the preconditions for economic growth and development. That is why it is important that these savings exist, regardless of whether the system can generate income sufficient to ensure a socially acceptable standard of living and their proper financing.

We can also say that saving through life insurance is a specific type of insurance because it is about insuring the risk of death, so it is the most widespread form of insurance around the world. There is almost no insurance company in the world that operates in highly developed countries, without offering life insurance savings in its portfolio as a form of insurance.

Life insurance savings in the Republic of Serbia are in a period of relative stability. Although there is a continuous growth, if the neighboring countries are taken into account, it is noticeable that this type of savings is still underdeveloped and is significantly below the average of the surrounding countries. Underdevelopment is even more noticeable when compared to European Union countries.

Through this paper, the attitude of the population in relation to savings through life insurance in the Republic of Serbia is analyzed in one place. All the above data show that the general hypothesis has been confirmed: Residents are not satisfied with the current state of savings through life insurance in the Republic of Serbia.

Through the analysis of data from the research, we come to the conclusion that the respondents believe that saving through life insurance is a good form of saving and that it is necessary. When it comes to trust, they agree that they do not trust this type of savings and that the conditions for the development of this type of savings are not favorable. They agree that the state does not pay enough attention to this type of savings. All respondents agree that they do not have enough money for this type of savings.

The general conclusion is that there is generally no significant difference in opinion regardless of gender, age, education, work experience and position of respondents in the company. 


\section{References}

Ćurčić, N., Piljan, I., \& Simonović, Z. (2019). Marketing concept in insurance companies Ekonomika, 65(3), 21-33. Doi: https://scindeks.ceon.rs/article.aspx?artid=0350137X1903021Q

Gvozdenović, N., \& Uzelac, O. (2018). Telematics and recent trends in automotive insurance and other types of insurance. Anali Ekonmskog fakulteta u Subotici, 54(39), 3343. Doi: https://doi.org/10.5937/AnEkSub1839033G

Kostadinović, I., \& Radojičić, J. (2017). Banking sector in the context of sustainable development. Economics of Sustainable Development, 1(2), 109-119.

Knežević, M., \& Đurić, Z. (2019). Some aspects of insurance development in Serbia. Ekonomika, 65(2), 39-49. Doi: https://doi.org/10.5937/ekonomika1902039K

Marković, T., \& Jovanović, M. (2010). Livestock insurance as a factor of economic stability in the agriculture. Contemporary Agriculture, 59(3-4), 287-292.

Marović, B., \& Avdalović, V. (2006). Osiguranje i teorija rizika. Beograd: Beogradska bankarska akademija.

Piljan, I., Cogoljević, D., \& Piljan T. (2015). Role of insurance companies in financial market. International Review, (1-2), 94-102.

Piljan, I., Cogoljević, D., \& Piljan, T. (2018). Osiguranje. Beograd: Visoka škola za poslovnu ekonomiju i preduzetništvo.

Piljan, T., Lukić, M., \& Piljan I. (2019). Necessity of introduction of pension disability insurance reform. International review, (1-2), 82-98.

Piljan, T., Piljan, I., \& Cogoljević, D. (2017). Insurance trends in Serbia from 2005 to 2015. Vojno delo, 69(5), 390-403. Doi: https://doi.org/10.5937/vojdelo1705390R

Vesić, T., Ravić, N., \& Đekić, M. (2019). Comparative analysis of the liquidity ratios of the largest banks of Serbia: Indicator of performance measurement. Anali Ekonomskog fakulteta u Subotici, (42), 3-15. Doi: https://doi.org/10.5937/AnEkSub1942003V 
